JAMP: Jurnal Adminitrasi dan Manajemen Pendidikan

Volume 1 Nomor 2 Juni 2018, Hal : 179-187

Tersedia Online di http://journal2.um.ac.id/index.php/jamp/

ISSN 2615-8574 (online)

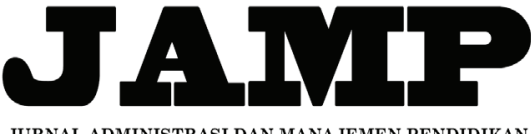

JURNAL ADMINISTRASI DAN MANAJEMEN PENDIDIKAN

\title{
MANAJEMEN HUBUNGAN SEKOLAH DAN MASYARAKAT BERBASIS ISLAM
}

\author{
Depi Indriani \\ Bambang Budi Wiyono \\ Ahmad Yusuf Sobri \\ depiindriani07@gmail.com \\ Universitas Negeri Malang, Jl. Semarang No. 5 Malang 65145
}

\begin{abstract}
The purpose of this study is to describe the public relations program, public relations techniques, public relations cooperation, public relations program stages, public relations evaluation, public relations management pattern, and constraints in managing public relations. This research uses qualitative approach and uses interview technique, observation, and documentation. The findings of this study identify that an institution to maintain its existence can not be separated from the participation of the community. It takes a partnership with the sharing of society such as business world and industrial world (DU / DI), alumni associations, school committees, foundations and madrasah assemblies. The process of public relations management in Islamic vocational schools in addition to paying attention to cooperation partners, also pay attention to program planning, techniques, patterns, stages, evaluation, and the possibility of obstacles in the implementation process.
\end{abstract}

Keywords: school and community relationships, techniques, cooperation, evaluation, constraints

\begin{abstract}
Abstrak : Tujuan dalam penelitian ini yaitu untuk mendiskripsikan program humas, teknik humas, kerjasama humas, tahapan program humas, evaluasi humas, pola manajemen humas, dan kendala dalam mengelola humas. Penelitian ini menggunakan pendekatan kualitatif dan menggunakan teknik wawancara, pengamatan, dan dokumentasi. Temuan penelitian ini mengidentifikasikan bahwa suatu lembaga untuk mepertahankan eksistensinya tidak terlepas dari partisipasi masyarakat. Dibutuhkan suatu mitra kerjasama dengan berbagi kalangan masyarakat seperti dunia usaha dan dunia industri (DU/DI), perkumpulan alumni, komite sekolah, yayasan serta majelis madrasah. Proses manajemen humas di sekolah menengah kejuruan berbasis islam selain memperhatikan mitra kerjasama, juga memperhatikan perencanaan program, teknik, pola, tahapan, evaluasi, serta kemungkinan terjadinya kendala dalam proses pelaksanaannya.
\end{abstract}

Kata Kunci : hubungan sekolah dan masyarakat, teknik, kerjasama, evaluasi, kendala

Pendidikan adalah usaha untuk mendewasakan dan memandirikan manusia dengan melalui kegiatan yang telah direncanakan serta melalui kegiatan belajar dan pembelajaran dengan melibatkan siswa dan guru, seluruh staff dan personil lembaga pendidikan yang berlandaskan pemikiran Al-quran dan AsSunnah dan suatu hal yang penting bagi pendidik untuk memberikan pembelajaran melalui berbagai metode dan model belajar yang sesuai dengan usia perkembangan peserta didik (Syam, 2016: 73).

Pendidikan islam adalah suatu proses yang diarahkan untuk membentuk kepribadian anak agar terbentuk suatu cara berpikir, merumuskan dan bertindak sesuai nilai-nilai islam serta dapat bertanggungjawab berdasarkan ajaran islam (Syam, 2016: 2). Di era sekarang ini beberapa lembaga 
pendidikan banyak yang mengedepankan pendidikan islam sebagai program-program utamanya. Tidak terkecuali pendidikan kejuruan yang saat ini juga banyak yang berbasis islam sebagai program-program unggulannya.

Program pemerintah membagi jenjang pendidikan Sekolah Menengah Atas (SMA) dan Sekolah Menengah Kejuruan (SMK) merupakan suatu cara untuk menyelenggarakan pendidikan yang layak. Sekolah kejuruan menurut Undang-Undang Negara Republik Indonesia Nomor 20 Tahun 2003 Pasal 18 merupakan pendidikan menengah yang dirancang untuk mengarahkan dan mempersiapkan peserta didik agar dapat bekerja pada bidang tertentu. Sebagai lanjutan dari penerapan undang-undang diatas, maka pendidikan kejuruan perlu dikembangkan. Tujuan dengan adanya Sekolah Menengah Kejuruan (SMK) yaitu untuk mempersiapkan siswa-siswi untuk masuk dunia kerja dan membentuk sikap yang professional, mempersiapkan peserta didik agar dapat menentukan karirnya, dapat berkompitisi serta mampu meningkatkan kualitas diri.

Lembaga sekolah dalam mewujudkan cita-cita suatu pendidikan berkaitan erat dengan manajemen hubungan sekolah dengan masyarakat. Manajemen hubungan sekolah dan masyarakat adalah suatu aktivitas komunikasi antara sekolah dan masyarakat dengan cara membantu, saling toleransi, saling memberi, sehingga timbul suatu hubungan kerjasama yang tidak saling merugikan dengan berbagai kalangan terkait dengan meningkatkan mutu pendidikan (Mulyono, 2008: 208).

Tujuan dari adanya hubungan sekolah dan masyarakat tersebut adalah untuk memajukan kesejahteraan masyarakat, mendapatkan bantuan sekolah dalam memecahkan permasalahan dalam masyarakat, dapat memberikan kecocokan antara progrm sekolah dengan kebutuhan masyarakat, serta mendapatkan kembali anggota-anggota masyarakat yang berdedikasi tinggi (Benty dan Gunawan, 2015: 9).

Kegiatan hubungan sekolah dan masyarakat disusun dalam bentuk program kerja rutin dan program kerja insidentil.Nasution (2010: 100-101) Program kerja rutin yaitu kegiatan yang dilakukan sehari-hari secara berkontinu dan kronologis, sedangkan program kerja insidentil yaitu kegiatan yang dilakukan pada periode tertentu (Nasution, 2010: 100-101). Selain itu menurut Purwanto (dalam Benty dan Gunawan, 2015: 87) untuk melaksanakan program-program tersebut, maka dibutuhkan teknik manajemen humas sebagai bentuk komunikasi antara sekolah dan masyarakat dengan maksud untuk meningkatkan pengertian masyarakat mengenai kebutuhan pendidikan dan untuk mendorong kemauan dan kerjasama masyarakat untuk perbaikan sekolah. Dalam meningkatkan partisipasi masyarakat dalam penyelenggaraan pendidikan di sekolah terdapat beberapa teknik yang dapat digunakan. Teknik tersebut diantaranya adalah teknik pertemuan kelompok, teknik tatap muka, observasi dan partisipan, dan surat menyurat dengan berbagai kalangan yang terkait dengan penyelenggaraan pendidikan.

Program kerja hubungan sekolah dan masyarakat dalam penyusunannya perlu memperhatikan beberapa tahapan. Tahapan program kerja humas menurut Rosady (dalam Benty dan Gunawan, 2015: 152) diantaranya adalah menelaah tingkah laku secara umum dan hubungan lembaga mengenai lingkungan, menentukan dan menafsirkan dengan benar tingkah laku pada setiap anggota kelompok terhadap organisasi, menguraikan tingkat aspirasi masyarakat secara intern maupun ekstern, mengantisipasi terjadinya suatu persoalan, kebutuhan dan kesempatan, memutuskan berbagai perumusan kebijakan, merencanakan suatu tindakan secara relevan untuk peningkatan tingkah laku kelompok masyarakat sasaran, menjalankan kegiatan yang berdasarkan program yang direncanakan, menerima feedback untuk proses evaluasi untuk menyesuaikan dengan apa yang diperlukan.

Pelaksanaaan program-program humas tersebut harus memperhatikan beberapa strategi untuk meningkatkan hubungan yang baik antara sekolah dan masyarakat. Contohnya seperti mengatasi persoalan yang timbul antara sekolah dan masyarakat juga merupakan cara agar dapat membangun hubungan yang baik antara sekolah dengan masyarakat. Jika terjadi permasalahaan dalam menjalin komunikasi, sekolah atau masyarakat dapat mengulangi informasi yang telah disampaikan apabila terdapat perselisihan antara kedua belah pihak. Tindakan tersebut merupakan suatu cara yang penting untuk mengantisipasi rasa berburuk sangka diantara kedua belah pihak dengan informasi yang sudah di sampaikan (Benty dan Gunawan, 2015: 132). 
Program-program humas yang telah dijalankan kemudian dilakukan proses evaluasi. Evaluasi program hubungan sekolah dan masyarakat adalah suatu cara mendeskripsikan, mengumpulkan dan menampilkan informasi mengenai program-program hubungan sekolah dan masyarakat agar suatu obyek dapat diketahui sehingga hasilnya dapat dan pada akhirnya dapat dijadikan pertimbangan untuk pengambilan keputusan. Prosedur dalam pengadaan evaluasi menurut Buckhori (dalam Minarti, 2011: 312) dapat dibedakan menjadi beberapa langkah. Langkah-langkah tersebut diantaranya adalah perencanaan tentang tujuan dari evaluasi, pengumpulan data, analisis data, serta penafsiran data. Sedangkan metode dalam proses evaluasi diantaranya adalah pengamatan, perekaman, peneliti melalui telepon, panel, daftar cek, skala penilaian, dan pol pendapat.

\section{METODE}

Metode dalam penelitian ini menggunakan pendekatan kualitatif untuk mencari informasi lebih mendalam mengenai manajemen hubungan sekolah dan masyarakat berbasis islam. Dalam mengumpulkan data penelitian, menggunakan teknik wawancara, pengamatan, dan dokumentasi. Data yang akan dikumpulkan terhadap penelitian ini diantaranya rencana kerja humas, teknik humas, kerjasama humas, tahapan program humas, pola manajemen humas, dan kendala dalam mengelola humas. Sumber data di lapangan diantaranya adalah Kepala Sekolah, Waka Humas, dan Komite Sekolah. Wawancara yang digunakan oleh peneliti adalah wawancara terstruktur dan wawancara semi terstruktur. Teknik wawancara tersebut dilaksanakan untuk mencari data informasi tentang manajemen hubungan sekolah dan masyarakat di SMK Darussalam dan dilaksanakan di lingkungan sekolah maupun luar sekolah pada waktu luang informan. Analisis data yang digunakan adalah reduksi data (data reduction), pemapaparan atau penyajian data (data display), dan menarik kesimpulan (conclusion drawing and verifying).

Pengecekan keabsahan data pada penelitian ini menggunakan tiga kriteria yaitu kredibilitas (credibility), keteralihan (transferability), kepastian (confirmability). Kriteria kredibilitas (credibility) adalah proses untuk melihat kesahihan sebuah data. Untuk melihat kredibilitas data atau validitas internal data dalam penelitian ini, peneliti menggunakan beberapa cara diantaranya adalah trianggulasi (trianggulation), pengecekan anggota, dan perpanjangan waktu pengamatan. Untuk keteralihan (transferability) merupakan pengujian sebagaimana validitas eksternal dalam penelitian kuantitatif. Sedangkan konfirmabilitas (confirmability) dalam penelitian kualitatif sama halnya untuk melihat keobjektifan dalam penelitian kuantitatif. Tahapan dalam penelitian ini diantaranya yaitu tahap pra lapangan, tahap pendahuluan, tahap penyusunan proposal, tahap pelaksanaan, dan tahap penyusunan laporan.

\section{HASIL}

\section{Perencanaan Hubungan Sekolah dan Masyarakat}

Program humas di SMK Darussalam Tulungagung diantaranya adalah rapat komite sekolah, pertemuan orangtua, penerimaan peserta didik (PPDB), publikasi sekolah, pameran pendidikan, kegiatan keagamaan bersama warga pondok dan masyarakat seperti sholat berjamaah, sholat dhuha, mengaji, Muwadda'ah, santunan anak yatim, dan prakerin.

Program-program hubungan sekolah dan masyarakat tersebut berkaitan erat dengan perencanaan untuk mewujudkan program tersebut dengan efektif dan efisien. Perencanaan program-program humas yang di bedakan menjadi 3 antara lain: (1) perencanaan program jangka pendek atau program harian merupakan program yang dilaksanakan setiap hari seperti rapat komite sekolah, pertemuan orangtua, sholat berjamaah, sholat dhuha, dan mengaji di pondok pesantren bersama warga pondok dan masyarakat, (2) perencanaan program jangka menengah yaitu dilakukan pada pertengahan semester atau pada hari besar agama seperti halal bihalal di Pondok Pesantren Darussalam sekaligus di rumah masyarakat, peringatan hari raya qurban, Muwadda'ah, zakat fitrah, santunan anak yatim, prakerin, dan menjalin hubungan kerjasama, dan (3) perencanaan program jangka panjang yaitu keikutsertaan sekolah dalam 
kegiatan syukuran desa maupun pesantren, kegiatan pesantren, dan mengefektifkan sumber potensial yang ada.

\section{Teknik Hubungan Sekolah dan Masyarakat}

Program humas dalam pelaksanaannya diperlukan beberapa teknik humas yang meliputi: teknik rapat, pertemuan orangtua, pameran pendidikan, teknik dokumentasi, pencetakan banner, kalender, brosur, dan melibatkan peserta didik untuk turun langsung dijalan untuk mempromosikan sekolah. Teknik manajemen hubungan sekolah dan masyarakat juga memerlukan media yang digunakan untuk mempublikasikan sekolah agar dikenal oleh masyarakat. Media yang digunakan diantaranya adalah melalui kalender, media sosial (website, whatsapp, facebook, email), brosur, reklame, dan banner.

\section{Kerjasama Hubungan Sekolah dan Masyarakat}

Manajemen hubungan sekolah dan masyarakat diperlukan adanya kerjasama terkait sekolah dan masyarakat untuk mewujudkan tujuan pendidikan. Pihak-pihak yang bekerjasama dengan SMK Darussalam Tulungagung antara lain komite sekolah, dunia usaha dan industri (DU/DI), perkumpulan alumni, yayasan serta majelis madrasah. Komite sekolah tersebut berasal dari sukarelawan atau lulusan dari Pondok Pesantren Darussalam. Untuk DU/DI pihak sekolah berkerjasama dengan dunia perbengkelan dan komputer dan masih mengutamakan kerjasama dengan DU/DI dalam daerah untuk mempermudah proses pengawasan. Selain itu sekolah juga membina hubungan yang baik dengan para lulusan Pondok Pesantren Darussalam. Pada akhirnya para lulusan tersebut menitipkan dan mempercayakan anak serta sanak saudara untuk menuntut ilmu di pondok pesantren sekaligus di sekolah tersebut. Para alumni berasal dari area Tulungagung, Banyuwangi dan Sumatera. Sedangkan untuk administrasi dan aktivitas belajar sekolah bekerjasama dan mangadopsi dari yayasan pondok pesantren Banyuwangi yang statusnya sebagai induk dari pondok pesantren Darussalam Tulungagung. Kemudian sekolah juga bekerjasama dengan majelis madrasah untuk meningkatkan mutu serta partisipasi masyarakat.

\section{Tahapan Hubungan Sekolah dan Masyarakat}

Tahapan-tahapan untuk melaksanakan program humas yang dilaksanakan oleh SMK Darussalam Tulungagung diantaranya adalah perencanaan (planning) yang merupakan cara untuk memutuskan tujuan serta prosedur yang akan dilakukan untuk mencapai suatu tujuan, pengorganisasian adalah usaha pengaturan atau penentuan tugas sesuai dengan kebutuhan, jabatan, wewenang, dan tanggungjawab, dan evaluasi merupakan suatu proses mengukur tentang sejauh mana program-program yang telah terlaksana.

\section{Pola Hubungan Sekolah dan Masyarakat}

Untuk membentuk relasi yang serasi antara sekolah dan masyarakat SMK Darussalam Tulungagung menciptakan pola humas sebagai berikut: (1) Adanya hubungan edukatif pihak sekolah dan masyarakat; (2) Membangun relasi yang serasi dengan cara memadukan kegiatan antara masyarakat dengan sekolah;

(3) Berpartisipasi pada setiap kegiatan adat istiadat desa setempat, (4) Menciptakan hubungan kerjasama yang saling bersinergi antara sekolah dengan industri dan perusahaan dengan sama-sama merasakan keuntungannya; (5) Memperhatikan opini masyarakat; dan (6) Mengadakan evaluasi bersama dengan berbagai pihak.

\section{Kendala Mengelola Hubungan Sekolah dan Masyarakat}

Dalam proses pelaksanaan program humas tentunya tidak selalu berjalan dengan mulus. Banyak persoalan-persoalan yang ditemui oleh SMK Darussalam Tulungagung, diantaranya adalah minimnya fasilitas sekolah dan minimnya komunikasi antara pihak sekolah dengan masyarakat pada akhirnya terjadi komunikasi satu arah. Namun kendala-kendala tersebut masih dapat diatasi oleh pihak sekolah. Seperti membangun opini yang positif di masyarakat melalui beberapa kegiatan yang melibatkan masyarakat serta prestasi yang dihasilkan oleh peserta didik sehingga dapat meningkatkan kerjasama masyarakat dengan sekolah seperti menghibahkan beberapa dana untuk pembangunan fasilitas sekolah dan meningkatkan komunikasi yang baik antara sekolah dengan masyarakat dengan penggunaan bahasa yang sederhana dan dapat dimengerti oleh berbagai kalangan masyarakat sehingga terwujud komunikasi yang baik antara sekolah dengan masyarakat. 


\section{PEMBAHASAN}

\section{Rencana Kerja Hubungan Sekolah dan Masyarakat}

Program kerja humas yang dilaksanakan di SMK Darussalam Tulungagung diantaranya adalah rapat komite sekolah, pertemuan orangtua, penerimaan peserta didik baru (PPDB), publikasi sekolah, pameran pendidikan, kegiatan keagamaan bersama warga pondok dan masyarakat seperti sholat berjamaah, sholat dhuha, mengaji, Muwadda'ah, santunan anak yatim, dan prakerin. Sedangkan perencanaan programprogram humas di SMK Darussalam Tulungagung diantaranya adalah perencanaan program jangka pendek atau program harian, program jangka menengah, dan perencanaan program jangka panjang.

Hasil temuan mengenai program humas tersebut selaras dengan pandangan Minarti (2012: 295300) bahwa program kerja humas dapat dibedakan menjadi dua kegiatan, yaitu kegiatan eksternal yang contohnya adalah rapat bersama dengan pengurus komite sekolah, bermusyawarah dengan tokoh-tokoh masyarakat, dan melayani kunjungan tamu, telepon, internet, faksimili, TV, radio, majalan/buletin sekolah, mading dan media cetak umum. Sedangkan mengenai perencanaan program humas selaras dengan pandangan Benty dan Gunawan (2015: 147-151) tentang program kerja humas yang hendaknya disusun melalui program kerja humas dalam program rutin (jangka pendek) dan program kerja insidentil (jangka panjang) yang dilaksanakan secara terus menerus dan kronologis.

\section{Teknik Hubungan Sekolah dan Masyarakat}

Teknik humas yang dilaksanakan oleh SMK Darussalam Tulungagung antara lain teknik rapat, pertemuan orangtua, pameran pendidikan, teknik dokumentasi, pencetakan banner, kalender, baliho, brosur, dan mengikutsertakan siswa-siswi untuk turun langsung dijalan untuk mempromosikan sekolah. pelaksanaan promosi sekolah di SMK Darussalam Tulungagung yaitu melalui pengenalan ke sekolahsekolah se-kabupaten Tulungagung, melalui event sekolah dan pondok pesantren serta keikutsertaan peserta didik dalam mempromosikan sekolah di luar jam kegiatan belajar mengajar. Sedangkan Media publikasi yang digunakan SMK Darussalam Tulungagung diantaranya adalah melalui kalender, media sosial (website, whatsapp, facebook, email), brosur, reklame, dan banner.

Hasil temuan mengenai teknik humas dan media humas tersebut selaras dengan pendapat Indrafachfrudi (dalam Benty dan Gunawan, 2015:89) yang mengungkapkan bahwa teknik penyelenggaraan humas dibagi menjadi empat, diantaranya adalah teknik pertemuan kelompok, teknik tatap muka, pengamatan dan partisipasi, dan surat menyurat dengan berbagai pihak. Pendapat lain yang selaras dengan teknik dan media diatas yaitu pendapat Mulyono (2011: 181) teknik hubungan sekolah dan masyarakat diantaranya adalah rapat bulanan pengajian umum, pekan perkenalan atau orientasi siswa baru, upacara bendera, dakwah keliling, kegiatan olahraga, pramuka atau camping atau perkemahan, kegiatan cinta alam, pameran, menyebarkan brosur, memasang spanduk, iklan di radio atau TV atau medi cetak, pertemuan wali murid, pertunjukan, menghadiri undangan atau pertemuan dan sebagainya.

\section{Kerjasama Hubungan Sekolah dan Masyarakat}

Kerjasama hubungan sekolah dan masyarakat merupakan suatu bentuk hubungan saling memberi antara sekolah dan masyarakat untuk mewujudkan suatu tujuan pendidikan. Kerjasama hubungan sekolah dan masyarakat berdasarkan informasi yang didapatkan di SMK Darussalam Tulungagung antara lain kerjasama dengan komite sekolah, dunia usaha dan industri (DU/DI), perkumpulan alumni pondok pesantren Darussalam Tulungagung, yayasan serta majelis madrasah.

Hasil temuan kerjasama humas di SMK Darussalam masih memiliki cakupan yang belum luas. Hal itu dapat dilihat berdasarkan pendapat Maisyaroh (dalam Benty dan Gunawan, 2015:46) mengenai kelompok-kelompok masyarakat yang dapat bekerjasama dalam bidang humas yaitu: (1) organisasi orangtua siswa dan guru; (2) orangtua secara individual; (3) keluarga orangtua; (4) asosiasi pembayar pajak; (5) city council; (6) school board (yayasan); (7) organisasi bisnis; (8) kelompok-kelompok yayasan; (9) kelompok-kelompok khusus yang berminat dalam bidang pendidikan; (10) pimpinanpimpinan bisnis penting; (11) dewan perdagangan; (12) organisasi veteran; (13) kelompok-kelompok pekerja; (14) kelompok-kelompok agama; (15) politikus; (16) organisasi persaudaraan; (17) organisasi 
kesejahteraan; (18) organisasi pemerintah; dan (19) pengelola pers, televisi, dan radio. Namun, kerjasama humas di SMK Darussalam Tulungagung lainnya sejalan dengan pandangan Benty dan Gunawan (2015: 57-63) yang mengungkapkan bahwa kelompok masyarakat yang terkait kerjasama dalam bidang humas diantaranya ialah dewan pendidikan, komite sekolah, dan majelis madrasah.

\section{Tahapan Hubungan Sekolah dan Masyarakat}

Tahapan guna melaksanakan program hubungan sekolah dan masyarakat merupakan suatu langkahlangkah dalam pencapaian tujuan atau sasaran program tersebut sesuai dengan yang direncanakan. Berdasarkan hasil temuan di SMK Darussalam Tulungagung pola pelaksanaan hubungan sekolah dan masyarakat di SMK Darussalam Tulungagung terdapat beberapa tahapan yaitu: perencanaan (planning), pengorganisasian (organizing), pelaksanaan (actuating), dan evaluasi (evaluation). Tahapan-tahapan tersebut dijalankan agar program-program humas dapat terlaksana dengan baik serta menciptakan komunikasi yang efektif antara sekolah dan masyarakat.

Hasil temuan mengenai tahapan program hubungan sekolah dan masyarakat kurang sejalan dengan pandangan Rosady (dalam Benty dan Gunawan, 2015: 152). Menurut Rosady (dalam Benty dan Gunawan, 2015:152) langkah-langkah untuk perencanaan program kerja terdapat beberapa tahapan sebagai berikut: (1) Menelaah tingkah laku secara luas dan relasi lembaga mengenai lingkungan; (2) Memutuskan dan mendalami dengan baik perilaku tiap-tiap kelompok pada organisasi; (3) Menguraikan tingkat pendapat masyarakat, baik intern maupun ekstern; (4) Memperkirakan terjadinya persoalan masalah yang potensial, kebutuhan dan peluang; (5) Memutuskan perumusan kebijakan; (6) Merancang suatu teknik untuk mewujudkan atau memperbaiki tingkah laku kelompok masyarakat sasaran; (7) Melakukan kegiatan yang sejalan dengan program yang direncanakan; (8) Mendapatkan feedback untuk proses evaluasi, kemudian mempersiapkan penyesuaian yang diperlukan.

\section{Pola Hubungan Sekolah dan Masyarakat}

Pola manajemen humas berdasarkan informasi yang didapatkan di SMK Darussalam Tulungagung diantaranya adalah: (1) Adanya hubungan edukatif oleh pihak sekolah dan masyarakat; (2) Mengadakan relasi yang baik dengan menggabungkan aktivitas masyarakat dan sekolah; (3) Berpartisipasi dengan kegiatan adat istiadat desa setempat; (4) Menciptakan hubungan kerjasama yang saling bersinergi antara sekolah dengan industri dan perusahaan sehingga tidak ada yang dirugikan; (5) Memperhatikan opini masyarakat; (6) Mengadakan evaluasi bersama.

Hasil temuan mengenai pola manajemen humas di SMK Darussalam memiliki pola tersendiri. Namun, masih sejalan dengan pandanganUmar (2016: 26-27) yang mengungkapkan bahwa pola relasi yang serasu antara sekolah dan masyarakat akan menciptakan hal-hal sebagai berikut: (1) Menimbulkan sikap A saling pengertian antara pihak sekolah dan masyarakat; (2) Adanya kegiatan saling membantu; (3) Adanya kerjasama yang erat dari berbagai pihak yang bertanggungjawab atas kesuksesan usaha pihak orang lain.

Tugas pokok atau beban kerja suatu sekolah tentang hubungannya dengan masyarakat menurut Umar (2016: 27) adalah: (1) Memberikan informasi dan menuangkan gagasan kepada masyarakat yang membutuhkannya; (2) Mendukung kepala sekolah dengan pekerjaan tidak dapat langsung memberikan informasi kepada masyarakat yang memerlukannya; (3) Mendukung kepala sekolah menyiapkan bahanbahan mengenai persoalan dan penjelasan yang akan disampaikan itu memikat reaksi masyarakat pada saat tertentu; (4) objektif dan serasi; (5) Memperhatikan opini masyarakat.

\section{Kendala Hubungan Sekolah dan Masyarakat}

Kendala merupakan sesuatu hal yang sering terjadi dalam membina hubungan antara sekolah dan masyarakat. Kendala bisa terjadi baik dari faktor luar maupun dalam. Kendala yang ditemui di SMK Darussalam diantaranya adalah minimnya sarpras dan kurangnya komunikasi dari pihak sekolah dengan masyarakat pada akhirnya terjadi komunikasi dua arah. Beberapa usaha untuk mengatasi kendala tersebut yaitu dengan membangun opini yang positif di masyarakat melalui beberapa kegiatan yang melibatkan masyarakat serta prestasi yang diwujudkan oleh para siswa sehingga menumbuhkan kerjasama masyarakat dengan sekolah seperti menghibahkan beberapa dana untuk pembangunan fasilitas sekolah 
dan meningkatkan komunikasi yang baik antara sekolah dengan masyarakat dengan penggunaan bahasa yang sederhana dan dapat dimengerti oleh berbagai kalangan masyarakat sehingga terwujud komunikasi yang baik antara sekolah dengan masyarakat.

Hasil temuan mengenai kendala-kendala dalam mengelola humas di SMK Darussalam tersebut sejalan dengan pandangan Pidarta (dalam Benty dan Gunawan, 2015: 103) yang menyatakan untuk membina hubungan antara sekolah dan masyarakat dalam prosesnya tidak selalu terlaksana dengan mudah seperti yang telah diharapkan. Tentunya terdapat kendala-kendala yang berakibat pada keharmonisan hubungan sekolah dan masyarakat. Kendala tersebut adalah: (1) rendahnya pemahaman masyarakat akan pendidikan dan juga rendahnya pemahaman warga sekolah tentang apa dan bagaimana seharusnya mengelola dan membangun hubungan dengan masyarakat, (2) rendahnya komunikasi antara warga sekolah dan masyarakat atau wali murid yang akibatnya sekolah kurang mengetahui harapan pada diri masyarakat namun menuntut harapannya pada masyarakat atau wali murid. Solusi untuk mengatasi kendala tersebut diantaranya adalah mengadakan laporan secara teratur tentang seluruh kegiatan sekolah serta keuangannya, dan diadakan berbagai kegiatan yang mengakrabkan seperti kunjungan rumah, kunjungan timbal balik, dan acara bersama seperti pentas seni atau perpisahan.

\section{KESIMPULAN DAN SARAN}

\section{Kesimpulan}

Rencana kerja humas di SMK Darussalam Tulungagung dilaksanakan dalam bentuk rapat komite sekolah, pertemuan sekolah, penerimaan peserta didik baru (PPDB), publikasi sekolah, pameran sekolah serta kegiatan keagamaan. Sedangkan perencanaan program sekolah dapat dibedakan menjadi 3 perencanaan, yaitu perencanaan jangka pendek, jangka menengah, dan jangka panjang. Selain itu sekolah juga membekali siswa dalam segi kerohanian dan ketrampilan atau skill. Hal itu merupakan upaya sekolah untuk menciptakan siswa yang berdedikasi tinggi dan diterima serta diakui oleh masyarakat. Upaya tersebut adalah sesuatu yang penting, karena mengingat sekolah tersebut merupakan sekolah yang masih merintis dan belum banyak masyarakat yang mengetahui adanya sekolah tersebut.

Teknik humas yang digunakan SMK Darussalam Tulungagung antara lain teknik rapat, pertemuan orangtua, pameran pendidikan, teknik dokumentasi, pencetakan banner, kalender, baliho, brosur dan mengikutsertakan siswa untuk turun langsung di jalan untuk mempromosikan sekolah. Pelaksanaan promosi sekolah di SMK Darussalam Tulungagung yaitu melalui pengenalan ke sekolah-sekolah se-kabupaten Tulungagung, melalui event sekolah dan pondok pesantren serta keikutsertaan peserta didik dalam mempromosikan sekolah di luar jam kegiatan belajar mengajar. Hal tersebut dimaksudkan sekolah untuk membentuk kepribadian siswa dan mengajarkan siswa agar dapat bersosialisasi yang baik dengan masyarakat.

Media humas yang digunakan di SMK Darussalam Tulungagung antara lain adanya website sekolah, facebook, email, whastapp, serta brosur sekolah. Media tersebut dapat memudahkan sekolah bertukar informasi serta membina relasi yang serasi dengan warga sekolah maupun masyarakat. Selain itu di era digital seperti sekarang beberapa orang banyak yang memakai internet untuk mengakses segala informasi karena relatif cepat dan mudah. Jadi dengan adanya media publikasi, sekolah dapat memperomosikan sekolah melalui postingan dokumentasi mengenai kegiatan-kegiatan sekolah di sosial media sehingga dapat menciptakan pendapat dari masyarakat mengenai sekolah tersebut.

Pihak-pihak yang menjalin kerjasama dengan SMK Darussalam Tulungagung adalah komite sekolah, dunia usaha dan dunia kerja (DU/DI), perkumpulan para alumni pondok pesantren Darussalam Tulungagung, yayasan serta majelis madrasah. Komite sekolah adalah sarana untuk menyalurkan aspirasi sekolah dengan masyarakat. Komite sekolah tersebut berasal dari sukarelawan atau dari lulusan Pondok Pesantren Darussalam. Untuk DU/DI pihak sekolah berkerjasama dengan dunia perbengkelan dan komputer dan masih mengutamakan kerjasama dengan DU/DI dalam daerah untuk mempermudah proses pengawasan. Selain itu sekolah juga menjalin hubungan yang baik dengan para alumni sehingga para alumni menitipkan dan mempercayakan anak serta sanak saudara untuk menuntut ilmu di pondok 
pesantren sekaligus di sekolah tersebut. Para alumni berasal dari area Tulungagung, Banyuwangi dan Sumatera. Sedangkan untuk administrasi dan kegiatan belajar sekolah bekerjasama dan mangadopsi dari yayasan pondok pesantren Banyuwangi yang statusnya sebagai induk dari pondok pesantren Darussalam Tulungagung. Kemudian sekolah juga bekerjasama dengan majelis madrasah untuk meningkatkan mutu serta meningkatkan partisipasi masyarakat.

Pelaksanaan pola hubungan sekolah dan masyarakat di SMK Darussalam Tulungagung meliputi perencanaan (planning), pengorganisasian (organizing), pelaksanaan (actuating), dan evaluasi (evaluation). Tahapan-tahapan tersebut dijalankan agar program-program humas dapat dilakukan secara efektif serta untuk menciptakan komunikasi yang baik antara sekolah dengan masyarakat.

Pola manajemen humas berdasarkan data yang di dapatkan di SMK Darussalam Tulungagung diantaranya adalah: (1) Adanya hubungan edukatif pihak sekolah masyarakat; (2) Membentuk relasi yang serasi dengan memadukan kegiatan di masyarakat dengan sekolah; (3) Berpartisipasi dengan kegiatan adat istiadat desa setempat; (4) Menciptakan hubungan kerjasama yang saling bersinergi antara sekolah dengan industri dan perusahaan sehingga tidak ada yang dirugikan; (5) Memperhatikan opini masy arakat; (6) Mengadakan evaluasi bersama.

Kendala atau hambatan dalam melaksanakana hubungan sekolah dan masyarakat di SMK Darussalam Tulungagung antara lain minimnya fasilitas dan rendahnya komunikasi antara pihak sekolah dan masyarakat kemudian terjadi komunikasi satu arah. Namun kendala-kendala tersebut masih dapat diatasi oleh pihak sekolah. Seperti membangun opini yang positif di masyarakat melalui beberapa kegiatan yang melibatkan masyarakat serta prestasi yang diwujudkan oleh siswa-siswi sehingga dapat menumbuhkan kerjasama masyarakat dengan sekolah seperti menghibahkan beberapa dana untuk pembangunan fasilitas sekolah dan meningkatkan komunikasi yang baik antara sekolah dengan masyarakat dengan penggunaan bahasa yang mudah dimengerti oleh berbagai kalangan masyarakat sehingga terbentuk komunikasi yang baikantara sekolah dengan masyarakat.

\section{Saran}

Peneliti memberikan saran kepada: (1) Yayasan Darussalam, dapat memperluas mitra kerjasama humas seperti bekerjasama dengan pengelola pers, televisi, radio, kelompok-kelompok yayasan lainnya, organisasi persaudaraan, dan sebagainya. Karena semakin luas kerjasama yang terjalin, maka sekolah dapat dikenal masyarakat dan dapat menambah mutu sekolah tersebut; (2) Kepala SMK Darussalam, agar meningkatkan dan memperluas jaringan kerjasama agar dapat memajukan kualitas sekolah, memberikan kesempatan pihak industri dalam memperoleh lulusan yang berdedikasi tinggi dan dapat memberikan pengalaman yang mendalam peserta didik; (3) Waka Humas SMK Darussalam Tulungagung, untuk lebih memperhatikan prosedur-prosedur dalam pelaksanaan evaluasi agar proses evaluasi dapat terlaksana secara maksimal; (4) Orangtua atau masyarakat untuk lebih meningkatkan kepeduliannya terhadap pendidikan dan mendukung sekolah untuk mewujudkan harapan yang telah dicita-citakan serta partisipasi tersebut diharapkan dapat dilakukan secara berkontinu; (5) Peserta didik diharapkan mampu saling bekerjasama mewujudkan program-program sekolah dengan cara meningkatkan prestasi siswa baik secara akademik maupun non akademik; (6) Dinas Pendidikan, dapat menjadi masukan untuk pengambilan kebijakan dalam upaya peningkatan mutu pendidikan terkait manajemen humas; dan (7) Peneliti lain, diharapkan dapat memperhatikan yang terkait dengan program humas, teknik humas, kerjasama humas, tahapan program humas, pola humas, dan kendala humas.

\section{DAFTAR RUJUKAN}

Benty, D. N, \& Gunawan, I. 2015. Manajemen Hubungan Sekolah dan Masyarakat. Malang: UM PRESS.

Minarti, S. 2011. Manajemen Sekolah: Mengelola Lembaga Pendidikan Secara Mandiri. Jogjakarta: Ar-Ruzz Media.

Minarti, S. 2012. Manajemen Sekolah: Mengelola Lembaga Pendidikan Secara Mandiri. Yogyakarta: Ar-Ruzz Media. 
Mulyono, 2008. Manajemen Adminsistrasi dan Organisasi Pendidikan. Jogjakarta: Ar-Ruzz Media.

Mulyono. 2011. Teknik Manajemen Humas dalam Pengembangan Lembaga Islam. (Online), (http://download.portalgaruda.org/article.php?article=

$313040 \& v a l=7502 \&$ title $=$ TEKNIK $\% 20$ MANAJEMEN\%20HUMAS\%20 DALAM\%20PENGEMBANGAN\%20LEMBAGA\%20 PENDIDIKAN\%2 OISLAM), diakses 18 Maret 2018.

Nasution, Z. 2010. Manajemen Humas di Lembaga Pendidikan. Malang: Universitas Muhammadiyah Malang Press.

Syam, J. 2016. Pendidikan Berbasis Islam yang Memandirikan dan Mendewasakan. (Online), (http://jurnal.umsu. ac.id/index.php/edutech/ article/view/600), diakses 22 Maret 2017.

Umar, M. 2016. Manajemen Hubungan Sekolah dan Masyarakat dalam Pendidikan. (Online), (http:download. portalgaruda.org/article.php?article $=\quad 449049 \& v a l=7458 \&$ title+MANAJEMEN\%HUBUNGAN520SEK OLAH\%20DAN\%20MASYARAKAT\%20DALAM\%20PENDIDIKAN), diakses 22 Maret 2017.

Undang-Undang Republik Indonesia Nomor. 2003. Tentang Sistem Pendidikan Nasional, Jakarta: Sinar Grafika. 